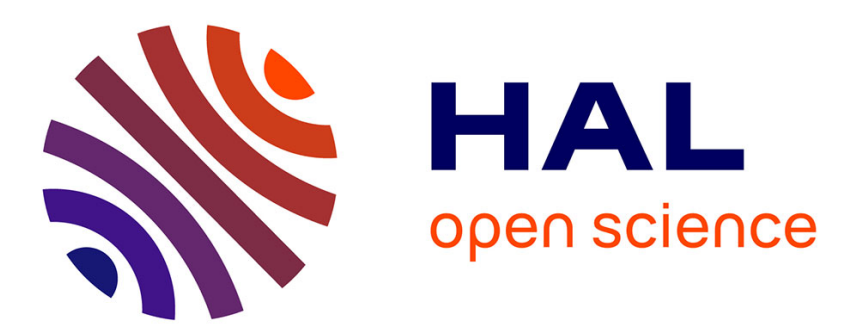

\title{
Rhodium-Catalyzed Crossed [2+2+2] Cycloaddition with Ynamides: Key-Strategy for the Concise Total Synthesis of 3-Oxygenated Carbazole Alkaloids
}

Carole Alayrac, Bernhard Witulski

\section{- To cite this version:}

Carole Alayrac, Bernhard Witulski. Rhodium-Catalyzed Crossed $[2+2+2]$ Cycloaddition with Ynamides: Key-Strategy for the Concise Total Synthesis of 3-Oxygenated Carbazole Alkaloids. Heterocycles, 2021, 103 (1, Spec. Iss.), pp.205-217. 10.3987/COM-20-S(K)24 . hal-02995341

HAL Id: hal-02995341

https://hal-normandie-univ.archives-ouvertes.fr/hal-02995341

Submitted on 8 Dec 2020

HAL is a multi-disciplinary open access archive for the deposit and dissemination of scientific research documents, whether they are published or not. The documents may come from teaching and research institutions in France or abroad, or from public or private research centers.
L'archive ouverte pluridisciplinaire $\mathbf{H A L}$, est destinée au dépôt et à la diffusion de documents scientifiques de niveau recherche, publiés ou non, émanant des établissements d'enseignement et de recherche français ou étrangers, des laboratoires publics ou privés. 


\title{
RHODIUM-CATALYZED CROSSED [2+2+2] CYCLOADDITION WITH YNAMIDES: KEY-STRATEGY FOR THE CONCISE TOTAL SYNTHESIS OF 3-OXYGENATED CARBAZOLE ALKALOIDS
}

\section{Carole Alayrac* and Bernhard Witulski*}

Laboratoire de Chimie Moléculaire et Thio-organique (LCMT), CNRS UMR 6507, ENSICAEN \& UNICaen, Norman-die Univ., 6 Bvd Maréchal Juin, 14050 Caen, France. E-mail : bernhard.witulski@ensicaen.fr

\section{Manuscript dedicated to Prof. Dr. Yasuyuki Kita on the celebration of his 77th birthday}

\begin{abstract}
Total syntheses of a set of naturally occurring 3-oxygenated carbazole alkaloids - 6-chlorohyellazole, carazostatin, carbazomycins A and B - are described. The key-strategy underlines a highly chemo- and regioselective rhodium-catalyzed $[2+2+2]$ cyclotrimerization between appropriately tailored yne-ynamides and 1-methoxypropyne that is stirred by the interplay of stereoelectronic and steric effects allowing the introduction of four ring substituents of the natural carbazoles within a single step and making the overall syntheses short and efficient.
\end{abstract}

Carbazole alkaloids are an important class of natural products displaying high diversity in their substitution pattern and revealing a broad range of biological activities. ${ }^{1}$ In the case of 3-hydroxycarbazole alkaloids, an alkyl chain is typically displayed at position C-1 but some exceptions are found. For example, hyellazole and 6-chlorohyellazole have the particularity of bearing a phenyl group at this position (Figure 1). Both are of marine origin and have been isolated from the blue-green alga Hyella caespitosa. ${ }^{2}$ Other 3-hydroxycarbazoles such as antiostatin $\mathrm{A}_{1},{ }^{3}$ carazostatin, ${ }^{4}$ and the carbazomycins $^{5} \mathrm{~A}$ and B were isolated from micro-organisms, Streptomyces cyaneus 2007-SV $\mathrm{S}_{1}$ Streptomyces chromofuscus, and Streptoverticillium ehimense H1051-MY 10, respectively.

Very recently, the carbazomycin B producing strain Streptomyces luteoverticillatus SZJ61 was isolated from marine sediment in China. ${ }^{6}$ Carbazomycins A and B are the first carbazole-related antibiotics possessing weak antibacterial and antiyeast activity and inhibit the growth of some phytopathogenic fungi. ${ }^{5 a, 6}$ Carbazomycin A displays weak cytotoxicity against cancerous (MCF-7, KB, NCI-H187) and noncancerous (Vero) cells. ${ }^{7}$ Carbazomycin B shows antimalarial activity against Plasmodium falaparum $\left(\mathrm{IC}_{50}\right.$ 
$=2.37 \mu \mathrm{g} / \mathrm{mL}) .^{7}$ Moreover, it is an inhibitor of 5-lipoxygenase ${ }^{8}\left(\mathrm{IC}_{50}=1.5 \mu \mathrm{M}\right)$ and exhibits inhibitory activity against lipid peroxidation induced by free radicals. ${ }^{9}$ The 3-hydroxycarbazoles antiostatin $\mathrm{A}_{1}$ and carazostatin are potent natural antioxidants. ${ }^{3,10}$ Carazostatin was shown to exhibit much stronger in vitro inhibitory activity against lipid peroxidation of rat brain homogenate $\left(\mathrm{IC}_{50}=0.17 \mu \mathrm{g} / \mathrm{mL}\right)$ than the well-known antioxidants, $\alpha$-tocopherol, the biological and chemically most active form of vitamin $\mathrm{E}$ ( $\mathrm{IC}_{50}$ $>100 \mu \mathrm{g} / \mathrm{mL})$, and the food additive $\operatorname{BHT}\left(3,5\right.$-tert-butyl-4-hydroxytoluene, $\left.\mathrm{IC}_{50}=4.89 \mu \mathrm{g} / \mathrm{mL}\right){ }^{9,11}$ Moreover, a strong ex vivo free radical scavenging activity of carazostatin in mouse blood plasma upon oral administration was demonstrated. ${ }^{9}$ In view of potential applications of antioxidants as therapeutic agents against free radical induced oxidative damage affecting DNA, lipids and proteins, ${ }^{12}$ radical scavengers such as antiostatin $A_{1}$, carazostatin and carbazomycin $\mathrm{B}$ are interesting targets for total synthesis.

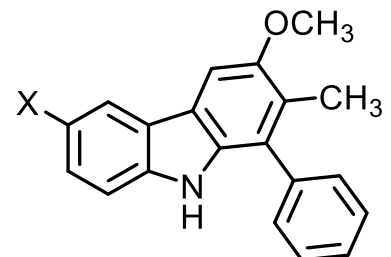

1a: hyellazole $(X=H)$

1b : 6-chlorohyellazole $(X=\mathrm{Cl})$

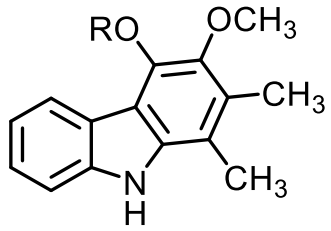

1c: carbazomycin $\mathrm{A}\left(\mathrm{R}=\mathrm{CH}_{3}\right)$

1d : carbazomycin $B(R=H)$

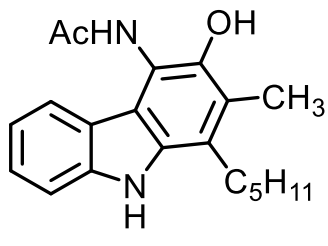

1e : antiostatin $A_{1}$

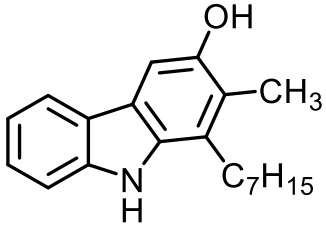

1f : carazostatin

Figure 1. Selected naturally occurring 3-oxygenated carbazoles

A literature survey on total syntheses of 3-oxygenated carbazole based natural products shows that the assembly of their scaffold relies on two main strategies (Scheme 1). The first one is the indole-to-carbazole approach $\left(A B \rightarrow A B C\right.$ ring construct). ${ }^{13}$ It comprises a variety of reactions such as $6 \pi$-electrocyclization, ${ }^{14}$ Diels-Alder reaction, ${ }^{15}$ Cadogan reaction, ${ }^{16}$ intramolecular Friedel-Crafts reaction, ${ }^{17}$ aldol condensation, ${ }^{18}$ or ring-closing metathesis. ${ }^{19}$ The second strategy $(A C \rightarrow A B C$ ring construct) involves the formation of the pyrrole unit from the $\mathrm{A}$ and $\mathrm{C}$ ring components that were assembled step-wise or in situ prior to ring closure. Transition metal-catalysis or metal free conditions were used to perform this ring closure from biphenylamines via $C-N$ bond ${ }^{20}$ or from $N, N$-diphenylanilines via $C$ - $C$ bond $^{21}$ forming reactions respectively (Scheme 1). Linking two aryl compounds and subsequent ring closure can be performed within a "one-pot procedure" using palladium catalysis ${ }^{22}$ or via an iron-mediated coupling between anilines and iron complex salts. ${ }^{23}$ Most of the reported routes towards carbazole alkaloids thus require multistep sequences to gain access to the required functionalized indole, biphenylamine or aryl halide precursors. A one-pot protocol ( $A \rightarrow A B C$ ring construct), however, should facilitate step and atom economical approaches towards biologically relevant functionalized and/or substituted carbazole alkaloids. ${ }^{24,25}$ 


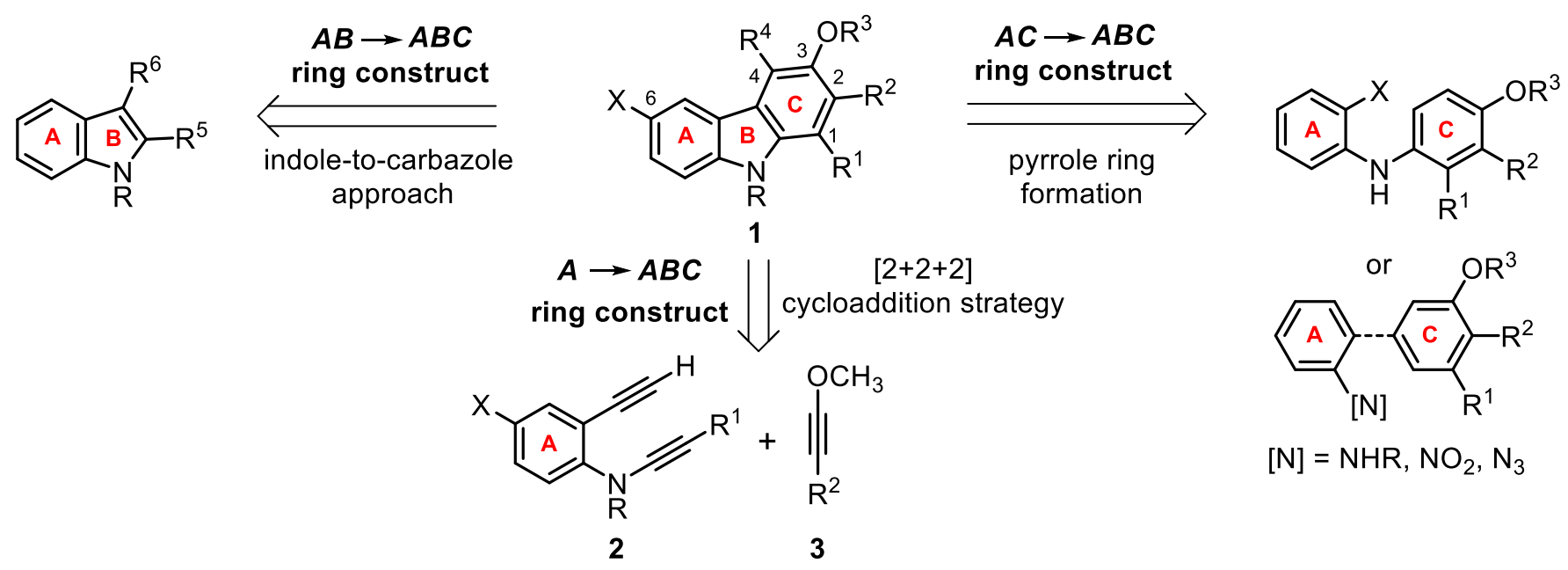

Scheme 1. Major strategies towards 3-oxygenated carbazole alkaloids

Some years ago we established the first reliable synthesis of functionalized ynamides applying alkynyl iodonium salts as $\mathrm{N}$-ethynylation reagents. ${ }^{26}$ The use of ynamides as novel building blocks and synthons in combination with transition metal catalyzed reactions opened new pathways towards $N$-heterocycles as being demonstrated by us $^{27}$ and others. ${ }^{28}$ However so far, the potential use of ynamides in total synthesis has been scarcely explored. ${ }^{29}$ Using ynamide chemistry we were able to achieve one of the shortest total syntheses of hyellazole ${ }^{25}$ (6 steps, 39\% overall yield) starting from commercially available 2-iodoaniline. Furthermore, the first total synthesis of antiostatin $A_{1}$ was realized by us in $16 \%$ overall yield and within 10 steps. ${ }^{30}$ Our respective strategy follows an $A \rightarrow A B C$ ring construct approach and is based on the transition metal catalyzed $[2+2+2]$ cycloaddition $^{31}$ between suitably functionalized diynes $\mathbf{2}$ and 1-methoxypropyne 3 , which allows the assembly of the carbazole core through the formation of three $C$ - $C$ bonds in a single step. In this report we wish to underline the usefulness of our developed methodology by further describing concise syntheses of naturally occurring 3-oxygenated carbazole alkaloids 6-chlorohyellazole, ${ }^{32}$ carazostatin, ${ }^{33}$ and the 3,4-dioxygenated carbazole natural products carbazomycins A and B. ${ }^{34}$

The diyne-ynamides 2a-c were prepared from the readily available precursors $\mathbf{5}$ and $\mathbf{8}$, which were synthesized from the commercially available 2-iodoanilines 4 and 7 respectively (Scheme 2). The $N$-ethynylation of anilide 5 with alkynyl iodonium salt $\mathbf{6}$ delivered $\mathbf{2 a}\left(\mathrm{X}=\mathrm{Cl}, \mathrm{R}^{1}=\mathrm{Ph}\right)$ in $60 \%$ isolated yield. The diynes $\mathbf{2} \mathbf{b}\left(\mathrm{R}^{1}=\mathrm{C}_{7} \mathrm{H}_{15}\right)$ and $\mathbf{2} \mathbf{c}\left(\mathrm{R}^{1}=\mathrm{Me}\right)$ were prepared by deprotonation of ynamide $\mathbf{8}$ with LiHMDS and alkylation with 1-iodoheptane and iodomethane respectively, followed by desilylation with TBAF. Compounds $\mathbf{2 b}$ and $\mathbf{2 c}$ were isolated in yields of 59\% and $87 \%$ (over 2 steps) respectively. 


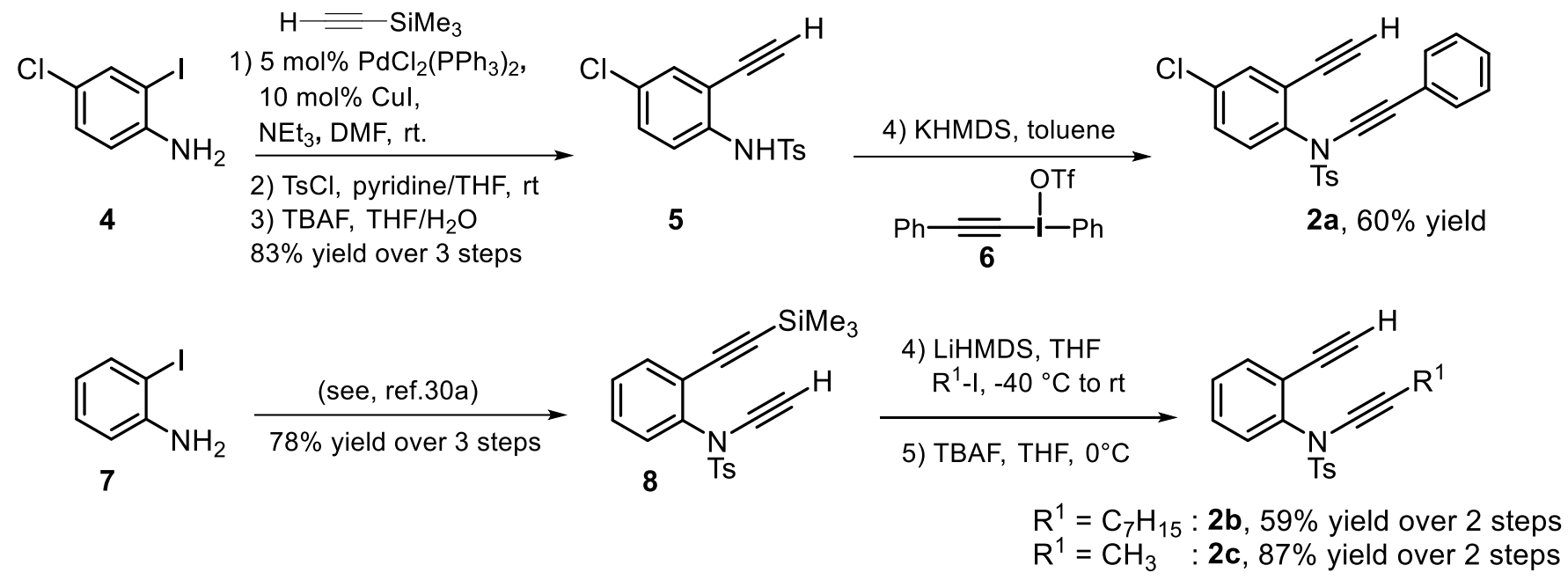

Scheme 2. Synthesis of diynes $\mathbf{2 a - c}$

A set of metal complexes classically used as catalysts in [2+2+2] alkyne cycloadditions ${ }^{31}$ was tested to compare their reactivity with that of Wilkinson's catalyst $\left[\mathrm{RhCl}\left(\mathrm{PPh}_{3}\right)_{3}\right]$. The latter was used by us already in the synthesis of hyellazole ${ }^{25}$ and antiostatin $\mathrm{A}_{1},{ }^{30 \mathrm{a}}$ as well as in the first total syntheses of alcyopterosins - distinctive phthalides of marine origin. ${ }^{35}$ The reaction between diyne $2 \mathbf{a}$ and 1-methoxypropyne (3) was selected as the model reaction. When the crossed [2+2+2] cycloaddition between diyne 2a and alkyne 3 (10 equiv.) was carried out in toluene at room temperature in the presence of $5 \mathrm{~mol} \%$ of $\left[\mathrm{RhCl}\left(\mathrm{PPh}_{3}\right)_{3}\right]$ the expected carbazole 9a was chemo- and regioselectively obtained (93\% yield, ratio of regioisomers $\mathbf{9 a} / \mathbf{9 b}=19: 1)$, (Table 1, entry 1). Extending the reaction time from 1 to 2 days gave a slightly higher yield (96\%) without affecting the isomer ratio (entry 2). In comparison, the catalytic activity of $\left[\mathrm{CoBr}\left(\mathrm{PPh}_{3}\right)_{3}\right]$ was significantly lower and was lacking any regioselectivity. A 1:1 mixture of the regioisomers $9 \mathbf{a}$ and $9 \mathbf{b}$ was isolated in $15 \%$ yield after 8 days at room temperature with a catalyst load of $10 \mathrm{~mol} \%$ of $\left[\mathrm{CoBr}\left(\mathrm{PPh}_{3}\right)_{3}\right]$ (entry 3). No significant change was observed when the reaction was performed at $60{ }^{\circ} \mathrm{C}$ (entry 4 versus 3 ). Iridium catalysis was tested using the catalyst system [ $\left.\mathrm{IrCl}(\mathrm{cod})_{2}\right](4 \mathrm{~mol} \%)$ and bis(diphenylphosphino)ethane (DPPE, $8 \mathrm{~mol} \%$ ). After 6 days at $60{ }^{\circ} \mathrm{C}$ carbazole 9a was formed as the major regioisomer $(9 \mathbf{a} / \mathbf{9 b}=6: 1)$ and isolated in $53 \%$ yield (entry 5 ). Moreover, the homotrimerisation products $\mathbf{1 0 a}$ and $\mathbf{1 0 b}$ of 1-methoxypropyne 3 were now isolated as side products in $39 \%$ yield (ratio of isomers $\mathbf{1 0 a} / \mathbf{1 0 b}=3: 2)$. The use of $\left[\mathrm{Ni}(\operatorname{cod})_{2}\right](20 \mathrm{~mol} \%)$ and triphenylphosphine $(20 \mathrm{~mol} \%$ ) as catalyst consumed the substrate $\mathbf{2 a}$ within 2 days at room temperature. However, only traces of the desired products $9 \mathbf{a}$ and $\mathbf{9 b}$ with a ratio of isomers of $9 \mathbf{a} / \mathbf{9 b}=1: 1$ were isolated (entry 6). Main products were now 10a and 10b, which were isolated in $30 \%$ yield (ratio of isomers $\mathbf{1 0 a} / \mathbf{1 0 b}=2: 3)$. The formal $[2+2+2]$ cycloaddition with the Grubbs' catalyst $(10 \mathrm{~mol} \%)-$ whose mechanism certainly differs from those of the other catalysts tested in this series and that most likely 
Table 1. Catalyst screening for the [2+2+2] cycloaddition of diyne 2a with 1-methoxypropyne 3

Catalyst
(see $\mathrm{Table} \mathrm{1)}$

(a) Isolated yield ${ }^{\text {(b) }}$ Isomer ratio determined from ${ }^{1} \mathrm{H}$ NMR spectrum. ${ }^{(\mathrm{c})}$ traces

(d) dichloro[1,3-bis(2,4,6-trimethylphenyl)-2-imidazolidinylidene](benzylidene)(tricyclohexylphosphine)ruthenium(II)

follows a cascade of ring-closing en-yne metathesis steps ${ }^{36}$ - only afforded carbazoles $9 \mathbf{a}$ and $9 \mathbf{b}$ in $13 \%$ yield. Furthermore, it was lacking any regioselectivity (ratio $\mathbf{9 a} / \mathbf{9 b}=1: 1$, entry 7 ). The side products $\mathbf{1 0 a}$ and $\mathbf{1 0 b}$ were formed in $5 \%$ yield with an isomer ratio of $\mathbf{1 0 a} / \mathbf{1 0 b}=3: 2$. This brief screening concludes that Wilkinson's catalyst displays the highest catalytic activity for the conversion of diyne 2a into carbazole 9a in view of significantly shorter reaction times, chemo- and regioselectivity, as well as being an operational simple transformation. Best chemoselectivities were observed with rhodium and cobalt, whereas iridium and nickel catalysts led to the formation of significant amounts of the side products 10a and 10b (30-39\% yield) through a homotrimerisation reaction of $\mathbf{3}$. The preferential formation of the regioisomer 9a is only observed with the rhodium and iridium catalysts. However, the regioselective outcome of this unique crossed [2+2+2] cycloaddition is much higher with the former (isomer ratio of $\mathbf{9 a} / \mathbf{9 b}=19: 1$ for Wilkinson's catalyst versus $6: 1$ for the iridium catalyst).

The total synthesis of 6-chlorohyellazole (1b) was now completed by $N$-tosyl group deprotection of 9a with TBAF (tetrabutylammonium fluoride) in refluxing dry THF delivering $\mathbf{1 b}$ in $97 \%$ yield (Scheme 4). Thus, the total synthesis of 6-chlorohyellazole (1b) was accomplished with $37 \%$ overall yield in a very short 6-step sequence starting from commercially available 4-chloro-2-iodoaniline. 


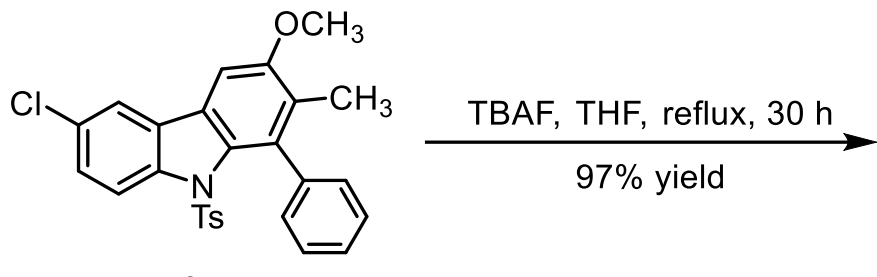

9a

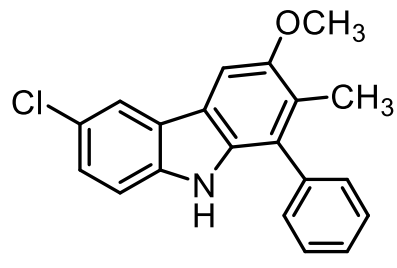

1b : 6-chlorohyellazole

Scheme 3. Synthesis of 6-chlorohyellazole (1b)

The crossed [2+2+2] cycloaddition of diyne $\mathbf{2 b}\left(\mathrm{R}^{1}=\mathrm{C}_{7} \mathrm{H}_{15}\right)$ with 1-methoxypropyne $\mathbf{3}$ was performed in toluene at room temperature in the presence of Wilkinson's catalyst $\left.\left[\mathrm{RhClPPh}_{3}\right)_{3}\right]$ and afforded carbazole 11 regioselectively with 65\% yield (regioisomer ratio 25:1) (Scheme 4). Isomerically pure 11 was obtained by column chromatography. Thereafter, only minor substituent modifications remained in order to complete the sequence towards carazostatin (1f): Removal of the $N$-tosyl group of 11 with TBAF gave the $9 H$-carbazole 12 ( $84 \%$ yield) that was then converted into carazostatin (1f, $80 \%$ yield) by treatment with $\mathrm{BBr}_{3}$ in $\mathrm{CH}_{2} \mathrm{Cl}_{2}$. Finally, the total synthesis of carazostatin was accomplished in only 8 steps from commercially available 2 -iodoaniline with $20 \%$ overall yield.

The crossed [2+2+2] cycloaddition of diyne $2 \mathrm{c}\left(\mathrm{R}^{1}=\mathrm{Me}\right)$ with alkyne 3 served in the synthesis of carbazomycins $\mathrm{A}$ and $\mathrm{B}$ and delivered the corresponding carbazole $13\left(\mathrm{R}^{1}=\mathrm{Me}\right)$ chemo- and regioselectively in $89 \%$ yield with 21:1 ratio of regioisomers (Scheme 4). Isomerically pure 13 was obtained by recrystallization (pentane $/ \mathrm{CH}_{2} \mathrm{Cl}_{2}$ ). Treatment of 13 with TBAF in refluxing THF gave 4-deoxycarbazomycin B (14) in 98\% yield. The $9 H$-carbazole 14 (4-deoxycarbazomycin B), that is a degradation product of natural carbazomycin B and a synthetic intermediate of the natural bicarbazole sorazolon $\mathrm{E},{ }^{37}$ displays inhibitory activity against Gram positive and negative bacteria. ${ }^{38}$

The synthesis of 4-hydroxycarbazole 16 - a common precursor of carbazomycins A and B - was achieved in analogy to a literature procedure from $13 .{ }^{34 \mathrm{~g}}$ The selective bromination of 13 using NBS ( $N$-bromosuccinimide) in acetonitrile (93\% yield) and subsequent formation of a boronic ester, which thereafter is treated in situ by $\mathrm{H}_{2} \mathrm{O}_{2}$ in basic medium gave the expected 4-hydroxycarbazole $16(\mathrm{R}=\mathrm{H})$. 4-Hydroxycarbazole 16 was isolated in 80\% yield along with carbazole 13 (15\% yield). O-Methylation of carbazole 16 gave 17 that was followed by removal of the $N$-tosyl group and finally afforded carbazomycin A (1c) in 95\% yield (2 steps). On the other hand, carbazomycin B (1d) was isolated in 14\% yield when the TBAF treatment was applied to 16. However, an overall higher yield of carbazomycin B (1d) of $28 \%$ over 2 steps was obtained by first protecting the hydroxy function of $\mathbf{1 6}$ as $O$-acetate to give 18, followed by the simultaneous deprotection of the $N$-tosyl and $O$-acetyl group with TBAF to deliver the targeted carbazomycin B (1d). Carbazomycins A and B were thus obtained in a quite short 10 step sequence starting from commercially available 2-iodoaniline with an overall yield of $43 \%$ and $12 \%$ 
respectively.

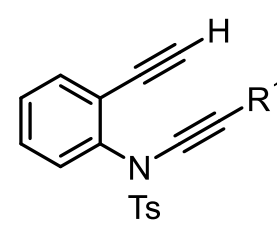

$\underset{5 \mathrm{~mol} \% \mathrm{RhCl}\left(\mathrm{PPh}_{3}\right)_{3}}{\stackrel{10 \text { equiv. } 3}{\longrightarrow}}$ toluene, rt, $2 \mathrm{~d}$

2b: $\mathrm{R}^{1}=\mathrm{C}_{7} \mathrm{H}_{15}$

2c: $\mathrm{R}^{1}=\mathrm{CH}_{3}$<smiles>[R]c1c(C)c(OC)cc2c3ccccc3n([13F])c12</smiles>

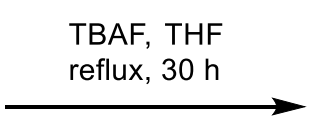

11: $\mathrm{R}^{1}=\mathrm{C}_{7} \mathrm{H}_{15}$,

$65 \%$ yield (ratio of isomers $25: 1$ )

13: $\mathrm{R}^{1}=\mathrm{CH}_{3}$,

$89 \%$ yield (ratio of isomers $21: 1$ )

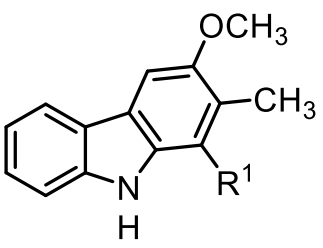

12: $\mathrm{R}^{1}=\mathrm{C}_{7} \mathrm{H}_{15}, 84 \%$ yield

14: $\mathrm{R}^{1}=\mathrm{CH}_{3}, \quad 98 \%$ yield 4-deoxycarbazomycine $B$

carazostatin (1f) $\frac{\mathrm{BBr}_{3}, \mathrm{CH}_{2} \mathrm{Cl}_{2}}{-78^{\circ} \mathrm{C} \text { to rt, } 80 \% \text { yield }}$<smiles>COc1c(C)c(C)c2c(c1Br)c1ccccc1n2[135I]</smiles>

15

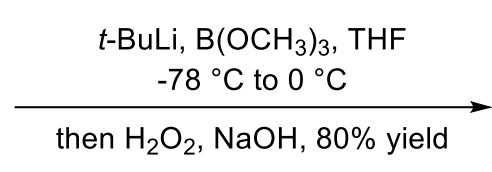

$\mathrm{Mel}, \mathrm{K}_{2} \mathrm{CO}_{3}$ acetone, $99 \%$ yield

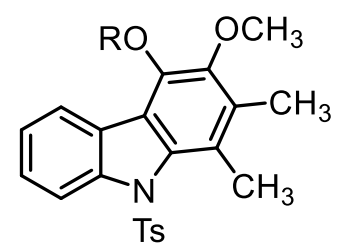

TBAF, THF reflux, $8-24 \mathrm{~h}$<smiles>[R20]c1c(OC)c(C)c(C)c2[nH]c3ccccc3c12</smiles>

$\mathrm{H}$
16: $\mathrm{R}=\mathrm{H}$

17: $\mathrm{R}=\mathrm{CH}_{3}$

18: $R=A c$
$\mathrm{Ac}_{2} \mathrm{O}$, pyridine $\mathrm{CH}_{2} \mathrm{Cl}_{2}$, $98 \%$ yield

carbazomycin A (1c): $R=M e, 96 \%$ yield

carbazomycin $B(1 d): R=H, 28 \%$ yield over 2 steps

Scheme 4. Synthesis of 4-deoxycarbazomycin B (14), carazostatin (1f), carbazomycin A (1c) and B (1d)

Although the synthetic utility of the transition metal catalyzed [2+2+2] alkyne cyclotrimerization has been recognized frequently since the first disclosure of the nickel catalyzed acetylene to benzene reaction by Reppe in the $1940 \mathrm{~s},{ }^{39}$ mechanistic understanding and details allowing to predict the chemo and regioselective outcome still remain unrevealed. Plausible mechanistic pathways for the reaction of di-ynamides $\mathbf{I}$ with 1-methoxypropyne $\mathbf{3}$ adapting a general mechanism proposed for the transition-metal-catalyzed $[2+2+2]$ cycloaddition reaction are outlined in Scheme 5.

The overall exergonic process from di-ynamide I to the final carbazoles VI covers the formation of three $C$ - $C$-bonds and gains aromatic stabilization. Ligand-alkyne substitution in Wilkinson's complex with diyne I followed by oxidative coupling results in the 18 electron complex II. Related rhodacyclopentadiene (rhodole) derivatives - that are best considered of being resting states in the catalytic cycle - have been isolated and characterized. ${ }^{40}$ Subsequent ligand dissociation (II to III-a/III-b) will generate vacant coordination sides for alkyne insertion. Electronically, rhodoles are best described 
with mesomeric structures comprising the rhodacyclopentadiene-III-a and the bis-carbene structure III-b. ${ }^{41}$<smiles>C#Cc1ccccc1N(C)C#CC</smiles>

I
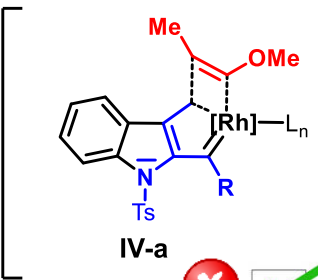

$x$

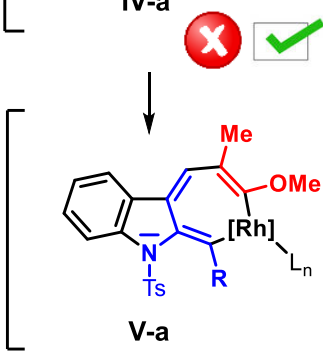

$-\left[\mathrm{Rh}\left(\mathrm{PPh}_{3}\right)_{n}\right]$

VI-b

minor isomer

(1) favored / disfavored stereoelectronics

favored / disfavored steric hindrance

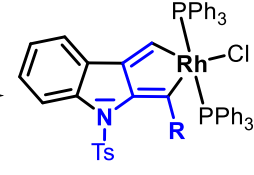

II
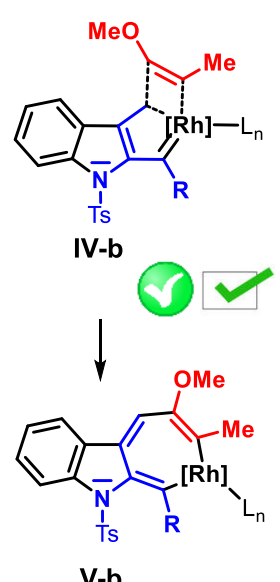

- $\left[\mathrm{Rh}\left(\mathrm{PPh}_{3}\right)_{n}\right]$

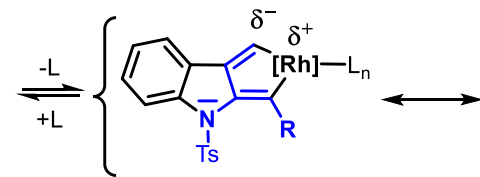

III-a $\mathrm{MeO} \frac{\delta^{+} \delta^{-}}{\overline{\overline{3}}} \mathrm{Me}$

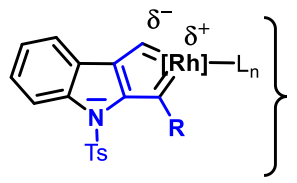

III-b

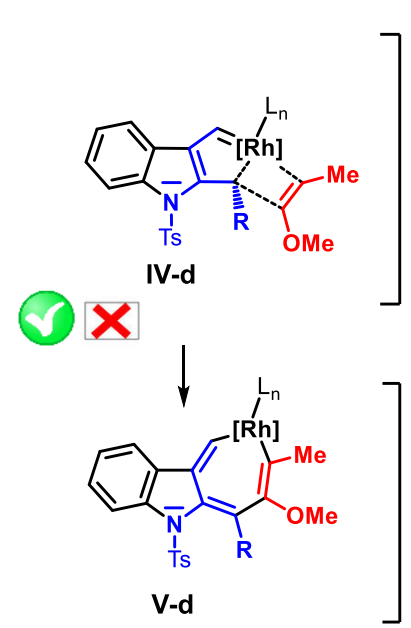
$-\left[\mathrm{Rh}\left(\mathrm{PPh}_{3}\right)_{n}\right]$

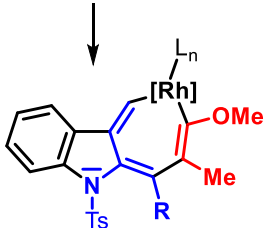

V-c

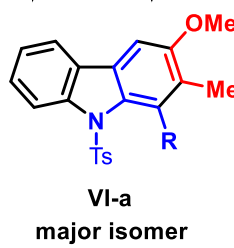

$\downarrow-\left[\mathrm{Rh}\left(\mathrm{PPh}_{3}\right)_{n}\right]$

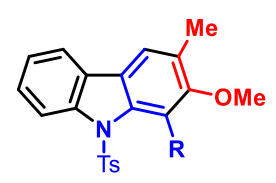

VI-b

minor isomer

Scheme 5. Proposed mechanistic pathways for the evaluation of steric and stereoelectronic effects stirring the rhodium catalyzed crossed [2+2+2] cycloaddition of ynamide $\mathbf{I}$ with 3-methoxypropyne $\mathbf{3}$ to give carbazoles VI-a/b

Formal [2+2] cycloaddition of alkyne 3 to one of the $C_{s p 2}-R h$ carbene bonds (to give IV) and subsequent ring-enlargement will give the rhodacycloheptatriene $\mathbf{V}$ that after reductive elimination and metal complex dissociation liberates carbazole VI. However, other scenarios describing the insertion step (i.e. Schore's mechanism, or a [4+2] Diels-Alder-type cycloaddition to give a metallanorbornadiene) are discussed in the literature. ${ }^{31}$

Rhodole formation is considered of being the rate determining step at least for the entirely intermolecular transition metal catalyzed $[2+2+2]$ cyclcoaddition. ${ }^{42}$ However, in the here discussed crossed version the formation of II and III-a/b should be easily accessible due to entropic reasons and the rate determining step therefore should be shifted to the mono-alkyne insertion process. This is in agreement with the exclusively high chemoselectivity observed for this reaction, as only trace amounts of the homotrimerization products of $\mathbf{3}$, the benzenes $\mathbf{1 0 a} / \mathbf{1 0 b}$, were found. 
The regioselective outcome of the reaction of $\mathbf{I}$ with 1-methoxypropyne $\mathbf{3}$ is reasoned as a result of the interplay of steric and electronic effects. Solely steric considerations were discussed in earlier contributions of this reaction, whereas electronic effects stirring the regioselectivity of transition metal catalyzed $[2+2+2]$ cycloadditions involving fully intermolecular or crossed enyne alkyne cycloadditions have been recognized only quite recently. ${ }^{43}$ Notably, the ynamide moiety in $\mathbf{I}$ as well as the 1-methoxypropyne $\mathbf{3}$ are electron rich alkynes with considerable charge distribution through the $C(\mathrm{sp})-C(\mathrm{sp})$ triple bond due to heteroatom- $C(\mathrm{sp}) \sigma$-bond inductive effects and $\mathrm{n}, \pi$-conjugation of the heteroatom lone pair with the $C(\mathrm{sp})-C(\mathrm{sp})$ triple bond. Such electronic effects will govern the orientation of the alkyne 3 in the insertion process along the formal [2+2] addition to the polarized $C_{\text {carbene }} R h$ bond having an electrophilic rhodium center. Eventually, such stereoelectronic effects should favor a reaction pathway along IV-b to $\mathbf{V}$-b with the methoxy-substituent oriented away from the rhodium center and insertion along the less substituted $\mathrm{C}_{\text {carbene }}-R h$ bond. Whereas the formation of IV-a and IV-c would contradict such a favorable orbital overlap during alkyne insertion. Furthermore, alkyne insertion along IV-b seems to be more favorable than involving IV-d due to steric reasons caused by the substituent R. Similar steric reasons would count for the relative energies of rhodacycloheptatrienes $\mathbf{V}$-a to $\mathbf{V}$-d from which V-d and V-c certainly show the highest sterically encumbered environment (1,2,3,4-substituted metallacycloheptatriene). Notably, the experimentally observed selectivity is extraordinarily high for this process and does not change significantly with the size of $\mathrm{R}(\mathrm{R}=\mathrm{Me}, n$-heptyl, $\mathrm{Ph})$. This is also an indication for the high preference of the insertion process along the less substituted $C_{\text {carbene }} R h$ bond to give IV-b. A more detailed mechanistic discussion, however, remains speculative as repulsion of substituents and especially alkyne substituents and phosphine ligands are not easily predictable - neither the number of phosphine ligands nor the complex geometry around the rhodium metal center in the rate determining step are known. However, the high regioselectivity found in the reaction of $\mathbf{2 a - c}$ with the alkyne 3 points to considerable contributions of stereoelectronic and steric effects to explain the outcome of the reaction and the almost exclusive formation of carbazoles VI-a. Work evaluating the contribution of stereoelectronic effect in the transition metal catalyzed [2+2+2] cycloaddition with ynamides is in progress.

In summary, the short total synthesis of several naturally occurring 3-oxygenated carbazole alkaloids was described. Common key step is the rhodium-catalyzed crossed alkyne [2+2+2] cycloaddition between yne-ynamides and 1-methoxypropyne, which proceeds with excellent chemo- and regioselectivities and allows the introduction of five benzene ring substituents of the natural carbazoles within a single step. This study highlights the applicability of the chemistry of ynamides - as well as the use of Wilkinson's catalyst with its high tolerance towards functional groups and its high regioselectivity in crossed $[2+2+2]$ alkyne cycloadditions - in the synthesis of natural products and drug related targets. 


\section{ACKNOWLEDGEMENTS}

Financial support of the Centre National de la Recherche Scientifique (CNRS), Normandie Université (RIN GreenChem), the Conseil Régional de Normandie and the Fonds Européen de Développement Régional (FEDER) is gratefully acknowledged.

\section{SUPPORTING INFORMATION}

Supplementary data (experimental procedures, spectroscopic and analytical data and copies of ${ }^{1} \mathrm{H}$ and ${ }^{13} \mathrm{C}$ NMR spectra) can be found, in the online version at URL: https://wwwheterocycles.jp

\section{REFERENCES}

1. Reviews: (a) A. Caruso, J. Ceramella, D. Iacopetta, C. Saturnino, M. V. Mauro, R. Bruno, S. Aquaro, and M. S. Sinicropi, Molecules, 2019, 24, 1912; (b) A. W. Schmidt, K. R. Reddy, and H.-J. Knölker, Chem. Rev., 2012, 112, 3193.

2. J. H. Cardellina II, M. P. Kirkup, R. E. Moore, J. S. Mynderse, K. Seff, and C. J. Simmons, Tetrahedron Lett., 1979, 20, 4915.

3. C.-J. Mo, K. Shin-Ya, K. Furihata, K. Furihata, A. Shimazu, Y. Hayakawa, and H. Seto, J. Antibiot., 1990, 43, 1337.

4. S. Kato, H. Kawai, T. Kawasaki, Y. Toda, T. Urata, and Y. Hayakawa, J. Antibiot., 1989, 42, 1879.

5. (a) K. Sakano, K. Ishimaru, and S. Nakamura, J. Antibiot., 1980, 33, 683; (b) K. Sakano and S. Nakamura, J. Antibiot., 1980, 33, 961; (c) M. Kaneda, K. Sakano, S. Nakamura, Y. Kushi, and Y. Iitaka, Heterocycles, 1981, 15, 993.

6. Z. Feng, G. Chen, J. Zhang, H. Zhu, X. Yu, Y. Yin, and X. Zhang, Curr. Microbiol., 2019, 76, 982.

7. C. Intaraudom, P. Rachtawee, R. Suvannakad, and P. Pittayakhajonwut, Tetrahedron, 2011, 67, 7593.

8. D. J. Hook, J. J. Yacobucci, S. O’Connor, M. Lee, E. Kerns, B. Krishnan, J. Matson, and G. Hesler, J. Antibiot., 1990, 43, 1347.

9. S. Kato, T. Kawasaki, T. Urata, and J. Mochizuki, J. Antibiot., 1993, 46, 1859.

10. (a) Y. Hieda, N. Hatae, M. Anraku, N. Matsuura, K. Uemura, S. Hibino, T. Choshi, H. Tomida, O. Hori, and H. Fujioka, Heterocycles, 2016, 92, 120; (b) Y. Hieda, M. Anraku, T. Choshi, H. Tomida, H. Fujioka, N. Hatae, O. Hori, J. Hirose, and S. Hibino, Bioorg. Med. Chem. Lett., 2014, 24, 3530.

11. M. Iwatsuki, E. Niki, S. Kato, and K. Nishikori, Chem. Lett., 1992, 1735.

12. 'Free Radicals in Biology and Medicine', ed. by B. Halliwell and C. Gutteridge, Oxford University Press, New York, 4th edn., 2004.

13. Review: T. Aggarwal, Sushmita, and A. K. Verma, Org. Biomol. Chem., 2019, 17, 8330. 
14. (a) A. Banerjee, S. Sahu, and M. S. Maji, Adv. Synth. Catal., 2017, 359, 1860; (b) Y. Hieda, T. Choshi, S. Kishida, H. Fujioka, and S. Hibino, Tetrahedron Lett., 2010, 51, 3593; (c) R. L. Danheiser, R. G. Brisbois, J. J. Kowalczyk, and R. F. Miller, J. Am. Chem. Soc., 1990, 112, 3093; (d) S. Hibino, A. Tonari, T. Choshi, and E. Sugino, Heterocycles, 1993, 35, 441; (e) S. Kano, E. Sugino, S. Shibuya, and S. Hibino, J. Org. Chem., 1981, 46, 3856.

15. (a) T. L. S. Kishbaugh and G. W. Gribble, Tetrahedron Lett., 2001, 42, 4783; (b) C. J. Moody, Synlett, 1994, 681.

16. (a) J. I. G. Cadogan, M. Cameron-Wood, R. K. Mackie, and R. J. G. Searle, J. Chem. Soc., 1965, 4831; (b) H. Srour, T.-H. Doan, E. Da Silva, R. J. Whitby, and B. Witulski, J. Mater. Chem. C, 2016, 4,6270 .

17. (a) S. B. Markad and N. P. Argade, Org. Lett., 2014, 16, 5470; (b) M. M. Heravi, V. Zadsirjan, P. Saedi, and T. Momeni, RSC Adv., 2018, 8, 40061.

18. E. Duval and G. D. Cuny, Tetrahedron Lett., 2004, 45, 5411.

19. T. Mandal, G. Chakraborti, S. Karmakar, and J. Dash, Org. Lett., 2018, 20, 4759.

20. (a) I. T. Alt and B. Plietker, Angew. Chem. Int. Ed., 2016, 55, 1519; (b) S. H. Cho, J. Youn, and S. Chang, J. Am. Chem. Soc., 2011, 133, 5996; (c) S. W. Yoon, J. H. Bihn, and B. S. Kim, Org. Lett., 2011, 13, 3738; (d) B. J. Stokes, B. Jovanovic, H. Dong, K. J. Richert, R. D. Riell, and T. G. Driver, J. Org. Chem., 2009, 74, 3225; (e) B.-J. Li, S.-L. Tian, Z. Fang, and Z.-J. Shi, Angew. Chem. Int. Ed., $2008,47,1115$.

21. (a) S. Lin, X. He, J. Meng, H. Gu, P. Zhang, and J. Wu, Eur. J. Org. Chem., 2017, 443, and ref. cited therein; (b) M. Sako, K. Ichinose, S. Takizawa, and H. Sasai, Chem. Asian J., 2017, 12, 1305.

22. N. D. Ca, G. Sassi, and M. Catellani, Adv. Synth. Catal., 2008, 350, 2179.

23. H.-J. Knölker, M. Bauermeister, D. Bläser, R. Boese, and J. B. Pannek, Angew. Chem. Int. Ed., 1989, 28, 223.

24. (a) S. Choi, V. Srinivasulu, S. Ha, and C.-M. Park, Chem. Commun., 2017, 53, 3481; (b) T. N. Poudel and Y. R. Lee, Chem. Sci., 2015, 6, 7028.

25. B. Witulski and C. Alayrac, Angew. Chem. Int. Ed., 2002, 41, 3281.

26. B. Witulski and T. Stengel, Angew. Chem. Int. Ed., 1998, 37, 489.

27. (a) V. Richard, M. Ipouck, D. S. Mérel, S. Gaillard, R. J. Whitby, B. Witulski, and J.-L. Renaud, Chem. Commun., 2014, 50, 593; (b) F. Nissen, V. Richard, C. Alayrac, and B. Witulski, Chem. Commun., 2011, 47, 6656; (c) B. Witulski, C. Alayrac, and L. Tevzadze-Saeftel, Angew. Chem. Int. Ed., 2003, 42, 4257; (d) B. Witulski and M. Gößmann, Chem. Commun., 1999, 1879; (e) B. Witulski, J. Lumtscher, and U. Bergsträßer, Synlett, 2003, 708; (f) B. Dassonneville, H. Detert, and B. Witulski, Eur. J. Org. Chem., 2011, 2836. 
28. For reviews on ynamides, see: (a) A. M. Cook and C. Wolf, Tetrahedron Lett., 2015, 56, 2377; (b) G. Evano, A. Coste, and K. Jouvin, Angew. Chem. Int. Ed., 2010, 49, 2840; (c) K. A. DeKorver, H. Li, A. G. Lohse, R. Hayashi, Z. Lu, Y. Zhang, and R. P. Hsung, Chem. Rev., 2010, 110, 5064; (d) B. Witulski and C. Alayrac, 'Compounds with Four and Three Carbon-Heteroatom Bonds - Science of Synthesis', Vol. 24, ed. by A. de Meijere, Georg Thieme, Stuttgart, 2005, pp. 1031-1058.

29. B. Witulski and J. Grand, 'Transition-Metal Mediated Aromatic Ring Construction', chapt. 7, ed. by K. Tanaka, J. Wiley \& Sons, Hoboken, New-Jersey, 2013, pp. 207-242.

30. (a) C. Alayrac, D. Schollmeyer, and B. Witulski, Chem. Commun., 2009, 1464; (b) K. E. Knott, S. Auschill, A. Jäger, and H.-J. Knölker, Chem. Commun., 2009, 1467.

31. For selected reviews, see: (a) M. Babazadeh, S. Soleimani-Amiri, E. Vessaly, A. Hosseinian, and L. Edjlali, RSC Adv., 2017, 7, 43716; (b) Y. Shibata and K. Tanaka, Synthesis, 2012, 44, 323; (c) G. Domínguez and J. Pérez-Castells, Chem. Soc. Rev., 2011, 40, 3430; (d) N. Agenet, O. Buisine, F. Slowinski, V. Gandon, C. Aubert, and M. Malacria, 'Organic Reactions', Vol. 68, ed. by T. V. Ranjan Babu, John Wiley \& Sons, Hoboken, 2007, pp. 1-302; (e) P. R. Chopade and J. Louie, Adv. Synth. Catal., 2006, 348, 2307; (f) I. Nakamura and Y. Yamamoto, Chem. Rev., 2004, 104, 2127.

32. For total synthesis of 6-chlorohyellazole, see: Ref. 14e, 17a, 18, 24b; (a) S. Chakraborty and C. Saha, Eur. J. Org. Chem., 2018, 2013; (b) E. M. Beccalli, A. Marchesini, and T. Pilati, J. Chem. Soc., Perkin Trans. 1, 1994, 579; (c) H.-J. Knölker, W. Fröhner, and R. Heinrich, Synlett, 2004, 2705.

33. For total synthesis of carazostatin, see: (a) P. M. Jackson and C. J. Moody, Synlett, 1990, 521; (b) P. M. Jackson, C. J. Moody, and R. J. Mortimer, J. Chem. Soc., Perkin Trans. 1, 1991, 2941; (c) K. Shin and K. Ogasawara, Chem. Lett., 1995, 289; (d) H.-J. Knölker and T. Hopfmann, Synlett, 1995, 981; (e) T. Choshi, T. Sada, H. Fujimoto, C. Nagayama, E. Sugino, and S. Hibino, Tetrahedron Lett., 1996, 37, 2593; (f) T. Choshi, T. Sada, H. Fujimoto, C. Nagayama, E. Sugino, and S. Hibino, J. Org. Chem., 1997, 62, 2535; (g) Y. Nonaka, T. Kawasaki, and M. Sakamoto, Heterocycles, 2000, 53, 1681; (h) H.-J. Knölker and T. Hopfmann, Tetrahedron, 2002, 58, 8937.

34. For total synthesis of carbazomycins, see: ref. 17a, 22, and (a) S. Wu, S. Harada, T. Morikawa, and A. Nishida, Chem. Pharm. Bull., 2018, 66, 178; (b) S. Singh, R. Samineni, S. Pabbaraja, and G. Mehta, Org. Lett., 2019, 21, 3372; (c) D. Crich and S. Rumthao, Tetrahedron, 2004, 60, 1513; (d) H.-J. Knölker and W. Fröhner, Tetrahedron Lett., 1999, 40, 6915; (e) E. M. Beccalli, A. Marchesini, and T. Pilati, Tetrahedron, 1996, 52, 3029; (f) D. L. J. Clive, N. Etkin, T. Joseph, and J. W. Lown, J. Org. Chem., 1993, 58, 2442; (g) C. J. Moody and P. Shah, J. Chem. Soc., Perkin Trans. 1, 1989, 2463; (h) J. Bergman and B. Pelcman, Tetrahedron, 1988, 44, 5215.

35. (a) T. Welsch, H.-A. Tran, and B. Witulski, Org. Lett., 2010, 12, 5644; (b) B. Witulski, A. Zimmermann, and N. D. Gowans, Chem. Commun., 2002, 2984; (c) B. Witulski and A. 
Zimmermann, Synlett, 2002, 1855.

36. (a) B. Witulski, T. Stengel, and J. M. Fernández-Hernández, Chem. Commun., 2000, 1965; (b) J.-U. Peters and S. Blechert, Chem. Commun., 1997, 1983; (c) S. K. Das and R. Roy, Tetrahedron Lett., 1999, 40, 4015.

37. (a) M. Sako, K. Ichinose, S. Takizawa, and H. Sasai, Chem. Asian J., 2017, 12, 1305; (b) S. Tasler and G. Bringmann, Chem. Rec., 2002, 2, 113.

38. C. Saha, A. Chakraborty, and B. K. Chowdhury, Indian J. Chem., 1996, 35B, 677.

39. W. Reppe, O. Schlichting, K. Klager, and T. Toepel, Justus Liebigs Ann. Chem., 1948, 560, 1.

40. (a) E. Müller, Synthesis, 1974, 761; (b) J. T. Mague, Inorg. Chem., 1970, 9, 1610; (c) R. G. Gastinger, M. D. Rausch, D. A. Sullivan, and G. J. Palenik, J. Organomet. Chem., 1976, 117, 355; (d) C. Bianchini, K. G. Caulton, C. Chardon, O. Eisenstein, K. Folting, T. J. Johnson, A. Meli, M. Peruzzini, D. J. Rauscher, W. E. Streib, and F. Vizza, J. Am. Chem. Soc., 1991, 113, 5127; (e) C. Bianchini, D. Masi, A. Meli, M. Peruzzini, A. Vacca, F. Laschi, and P. Zanello, Organometallics, 1991, 10, 636; (f) M. Parera, A. Dachs, M. Sola, A. Pla-Quintana, and A. Roglans, Chem. Eur. J., 2012, 18, 13097.

41. The bis-carbene structure (rhodacyclopentatriene) III-b is considered of being a mesomeric form of rhodole III-a that is discussed along the general mechanism of transition metal catalyzed alkyne cyclotrimerizations. Considerable double bond character of the $\mathrm{Rh}-\mathrm{C}$ bond by $\pi$ back-bonding was observed in X-ray structures of related rhodole derivatives, see for instance lit. 40b. Notably, bis-carbene structures of related ruthenium complexes that catalyze $[2+2+2]$ cycloadditions are also discussed and evidenced, see: Y. Yamamoto, in 'Transition-Metal Mediated Aromatic Ring Construction', chapt. 3, ed. by K. Tanaka, J. Wiley \& Sons, Hoboken, New-Jersey, 2013, pp. 71-125, and ref. cited therein.

42. (a) A. Dachs, S. Osuna, A. Roglans, and M. Solà, Organometallics, 2010, 29, 562; (b) A. Dachs, A. Torrent, A. Pla-Quintana, A. Roglans, and A. Jutand, Organometallics, 2009, 28, 6036.

43. (a) D. W. Crandell, S. Mazumder, P. A. Evans, and M.-H. Baik, Chem. Sci., 2015, 6, 6896; (b) O. Torres, M. Fernàndez, A. Díaz-Jiménez, A. Pla-Quintana, A. Roglans, and M. Solà, Organometallics, 2019, 38, 2853. 